\title{
Strategi Kebijakan Menjaga Warisan Budaya Bandar Aceh Darussalam Di Kota Banda Aceh, Provinsi Aceh
}

\author{
Policy Strategies to Maintain Cultural Heritage of Bandar Aceh \\ Darussalam In Banda Aceh City, Aceh Province
}

\author{
Ambo Asse Ajis \\ Balai Pelestarian Cagar Budaya Aceh \\ ambo.unsam@gmail.com
}

\begin{abstract}
ABSTRAK
Bandar Aceh Darussalam adalah ibukota Kerajaan Aceh Darussalam sejak intitusi pemerintahan Islam ini didirikan oleh Sultan Ali Mugahayat Syah tahun 1496 Masehi. Ketika penjajah Belanda berhasil menguasainya di tahun 1874, ibukota ini diganti dengan nama Kutaraja. Ketika Aceh menjadi bagian Indonesia, Kutaraja berganti nama menjadi Banda Aceh pada tahun 1962. Sebagai bekas ibukota kerajaan, seluruh tanah di Bandar Aceh Darussalam tentu menyimpan deposit jejak budaya yang memiliki nilai penting bagi identitas Aceh secara khusus dan Indonesia secara umum. Meskipun demikian, karena berada dalam areal inti perkotaan Kota Banda Aceh dan sekaligus Ibukota Provinsi Aceh, potensi warisan budaya budaya tersebut sedang menghadapi ancaman yang tinggi karena terganggu akibat konflik kepentingan, baik itu atas nama kepentingan penduduk maupun kepentingan pembangunan pemerintah Kota Banda Aceh, Provinsi Aceh hingga pembangunan Nasional. Terkait dengan hal itu, tulisan ini dibuat dengan tujuan mengajukan pemikiran penangan potensi konflik dengan pendekatan cultural resource management (CRM) yang dapat diterapkan para stakeholder terkait rencana pelestarian kawasan kuno Bandar Aceh Darussalam.
\end{abstract}

Kata Kunci: kutaraja; kerajaan aceh darussalam; konflik kepentingan; manajemen sumberdaya budaya

\section{ABSTRACT}

Bandar Aceh Darussalam is the capital of the Kingdom of Aceh Darussalam since the Islamic government institution was founded by Sultan Ali Mugahayat Syah in 1496 AD. When the Dutch colonizers succeeded in mastering it in 1874, the capital was replaced with the name Kutaraja. When Aceh became part of Indonesia, Kutaraja changed its name to Banda Aceh in 1962. As a former capital of the kingdom, all land in Bandar Aceh Darussalam certainly saved deposits of cultural traces that had important values for Acehnese identity in particular and Indonesia in general. However, because it is in the urban core area of Banda Aceh City and at the same time the Capital of Aceh Province, the potential of cultural cultural heritage is facing a high threat because it is disrupted due to conflicts of interest, both in the name of population interests and the development interests of the Banda Aceh, Provincial National development. In this regard, this paper was created with the aim of proposing a potential conflict handling thinking with a cultural resource management (CRM) approach that can be applied by stakeholders regarding the plan to preserve the ancient area of Bandar Aceh Darussalam.

Keywords: kutaraja; kingdom of aceh darussalam; conflict of interest; cultural resource management approach 


\section{PENDAHULUAN}

Bandar Aceh Darussalam merupakan tofonim kuno dari areal pusat pemerintahan (ibukota) Kerajaan Aceh Darussalam pada masa lampau yang berlangsung dari tahun 1496 sampai tahun 1874 Masehi. Sejak diproklamasikan oleh Sultan Ali Mughayat Syah Tahun sebagai pusat pemerintahan Kerajaan Aceh, ibu kerajaan Aceh ini berkembang sesuai dengan tuntutan kondisi dari masa ke masa.

Pada masa sekarang, tinggalan warisan budaya berupa bangunan fisik yang masih terlihat tidak banyak lagi yang tersisa karena hilang akibat bencana alam (seperti: tsunami, banjir) maupun akibat peperangan yang terjadi di masa lalu. Sementara peninggalan yang tersisa sendiri, sebagiannya ada yang terawat dan juga tidak terawat.

Pada masa lalu, sejarah menyebutkan bahwa cukup banyak bangunan fisik yang dibangun oleh Sultan dan Sultanah Kerajaan Aceh. Misalnya, 1) pembangunan Istana dan kawasan Istana yang digelar dengan sebutan Daruddonya beserta asosiasinya seperti dinding benteng, pembangunan taman ghairah, pembangunan kanal Krueng Daroy yang mengalir dari sumber mata air di pegunungan Mata Ie ke areal istana serta dibangunnya monumen yang dikenal dengan sebutan gunongan pada era Sultan Iskandar Muda (1607-1636 Masehi); 2) pembangunan masjid raya Bait al-Rahman dan pembangunan ulang masjid tersebut akibat kebakaran pada era Ratu Shafiatuddin (1641-1675 Masehi); 3) pembangunan benteng pertahanan di berbagai tempat, seperti benteng Iskandar Muda, perkuatan benteng Indrapatra, pembangunan benteng
Inong Balee, perkuatan benteng Kuta Lubok dan lain sebagainya.

Namun, hal yang perlu juga dipahami bahwa sebelum Kerajaan Aceh terbentuk tahun 1496 Masehi dan menjadikan Bandar Aceh Darussalam sebagai ibu kerajaannya, wilayah ini pernah di bawah kekuasaan Kerajaan Lamuri sebagaimana bukti tinggalan arkeologis berapa sebaran nisan kuno tipe Lamuri yang banyak tersebar di lokasi ini.

Demikian juga disebut pernah di bawah kekuasaan Kerajaan Pedir (Syir Duli) sebagaimana laporan Veltmen. Sumber Portugis mengatakan bahwa Sultan Ma'ruf Syah Raja Fadir (Syir Duli) itu pernah menaklukkan Acah Besar di tahun 1497. Pada masa itu diangkatnya dua orang wakil di Aceh, seorang di Aceh sendiri dan seorang di Daya (letak negeri Daya berada di sebelah barat Kota Banda Aceh dan saat ini masuk dalam wilayah Kabuaten Aceh Besar).

Dengan kata lain, jauh sebelum Bandar Aceh Darussalam menjadi pusat Kerajaan Aceh, telah ada permukiman yang besar di lokasi ini dan semakin berkembang setelah dijadikan sebagai pusat ibukota Kerajaan Aceh.

Ketika penjajah Belanda merebut pusat kerajaan Aceh tahun 1874 Masehi, nama Bandar Aceh Darussalam diganti dengan nama Kutaraja, difungsikan sebagai pusat administratif penjajahan mereka di Aceh. Dari lokasi ini, kebijakan penjajahan dibuat dan dilaksanakan yang tentu saja mendapatkan perlawanan dari para pejuang Kesultanan Aceh hingga tahun 1942 Masehi.

Pada masa kini, Kutaraja berganti menjadi Kota Banda Aceh 
dan memiliki 9 (sembilan)

kecamatan, yakni Baiturahman, Banda Raya, Jaya Baru, Kuta Alam, Kutaraja (Kuta Raja), Lueng Bata, Meuraksa, Syiah Kuala, dan Ulee Kareng.

Salah satu pusat Kerajaan Aceh di masa lalu, berada di areal geografis kecamatan Kutaraja, tersebar di 6 (enam) gampong (desa) yaitu Gampong Pande, Gampong Jawa, Gampong Keudah, Gampong Peulanggahan, Gampong Lampaseh dan Gampong Merduati.

Kecamatan Kutaraja ini merupakan pecahan dari kecamatan Kuta Alam yang terpisah sejak tahun 2000 berdasarkan Peraturan Daerah Kota Banda Aceh Nomor 8 Tahun 2000. Kecamatan ini memiliki cukup banyak kandungan situs cagar budaya maupun diduga cagar budaya, tersebar dengan kondisi yang berbeda-beda. Misalnya, ada yang telah memiliki status sebagai cagar budaya, ada yang baru diregistrasi sebagai objek di duga cagar budaya dan bahkan ada yang baru disurvei tetapi belum diregistrasi.

Kedudukannya sebagai salah satu areal bekas pusat pemerintahan Kerajaan Aceh Darussalam menyebakan Kecamatan Kutaraja memiliki potensi tinggalan arkeologi yang berlimpah sekaligus bernilai sangat penting baik dari sudut pandang historiografi Aceh, Indonesia bahkan sejarah Asia.

Nilai penting bagi historiografi Aceh karena dari tempat inilah sejarah Kerajaan Aceh dimulai dari tahun 1492 Masehi hingga 1874 Masehi, lalu pindah akibat serangan kolonial Belanda dengan beribu kota ke Pidie sejak tahun 1874 Masehi sampai dengan 1942 Masehi. \begin{tabular}{llll}
\multicolumn{2}{r}{ Meskipun } & memiliki & nilai \\
penting bagi & sejarah, & ilmu
\end{tabular} pengetahuan, pendidikan, agama dan budaya, kenyataannya jejak masa lampau yang tersebar di areal Kecamatan Kutaraja saat ini sedang menghadapi ancaman penggerusan akibat sengketa kepentingan, seperti konflik penggunaan tanah baik itu pribadi maupun kepentingan pembangunan.

Sepertinya, konflik kepentingan penggunaan lahan di Kecamatan Kutaraja Banda Aceh yang pernah menjadi bekas ibukota Kerajaan Aceh Darussalam selama 500 tahun lebih adalah hal yang tidak terhindarkan saat ini dan di masa yang akan datang. Faktor meningkatnya kebutuhan lahan baik keperluan warga maupun kepentingan pembangunan adalah dua motif utama yang seringkali muncul di tengah keterancaman hilangnya sedikit demi sedikit jejak warisan budaya masa lampau di kawasan bekas pusat aktivitas kerajaan Aceh Darussalam.

Apa yang terjadi di Kota Banda Aceh, ternyata juga terjadi di banyak tempat di Indonesia. Contoh terbaru, kasus pembangunan Tol Yogyakarta-Solo dimana rencana rute awalnya akan melalui banyak situs cagar budaya, tetapi atas desakan Gubernur Yogyakarta, rencana rute tersebut sedang dipikirkan ulang oleh para pihak. Demikian juga kasus Mega proyek Majapahit Park atau Pusat Informasi Majapahit di Museum Trowulan, Mojokerto, Jawa Timur tahun 2009 yang pembangunannya telah merusak sejumlah situs purbakala seperti batu bata, sumur, gerabah, hingga pelataran rumah kuno sebagaimana yang diungkapkan Mantan Kepala 
Sub Balai Pelestarian Peninggalan Purbakala Jatim, Endro Waluyo, tahun 2009 lalu ada contoh kongkrit seringkalinya konflik terjadi di atas tanah warisan budaya.

Konflik pembangunan yang sama, dialami kawasan Kutaraja, Kota Banda Aceh, Provinsi Aceh pada tahun 2017 lalu dan hingga saat ini kasusnya masih menggantung dan belum ada kepastian. Riwayat kasusnya terjadi akibat pembangunan fisik proyek Instalasi Pengelolaan Air Limbah (IPAL) tahun 2016-2019 yang letaknya di Gampong Jawa dan Gampong Pande, Kecamatan Kutaraja, Kota Banda Aceh. Kedua gampong ini merupakan bagian utama dari wilayah inti Kutaraja, pusat pemerintahan Kesultanan Aceh Darussalam.

Riwayat kasus IPAL bermula ketika kebijakan pemerintah Kota Banda Aceh menempatkan lokasi pembangunan kompleks IPAL berada di tepi Krueng Aceh (Sungai Aceh) pada tahun 2002 lalu. Saat itu, protes atas rencana pembangunan sudah mulai ada. Ketidaksetujuan warga Gampong Pande lebih pada kurang terbukanya pengelola kegiatan dalam mensosialisasikan tujuan proyek tersebut. Apalagi, di dekat lokasi proyek IPAL juga sudah ada lokasi tempat pembuangan sampah (TPA) yang sudah bertahun-tahun beroperasi dan menimbulkan polusi udara bagi warga sekitarnya.

Meskpun ada suara keberatan karena kurangnya partisipasi, pembangunan fisik mulai dilakukan tahun 2016 dan pada saat pelaksanaan, secara tidak terduga menemukan nisan-nisan kuno berciri abad ke-17 hingga ke-18 Masehi di lokasi tersebut. Akibat penemuan material yang di duga cagar budaya tersebut, pun sekaligus menjadi katalisator warga dan pemerhati cagar budaya untuk memprotes kegiatan pembangunan IPAL. Protes mengalir tiada henti, memasuki ranah politik praktis mulai dari tingkat Gampong (desa), Kecamatan, Kota Banda Aceh, Provinsi Aceh sampai di tingkat Nasional.

Tokoh budaya, mahasiswa, pemuda, LSM, tokoh politik dan lembaga pemerintah berdialektika mencari penyelesaian kasus konflik pembangunan tersebut. Di sisi lain pemerintah Kota Banda Aceh melakukan komunikasi dengan pihak Kementerian Pekerjaan Umum di Jakarta meminta waktu untuk menyelesaikan protes warga.

Alhasil, Walikota Banda Aceh, membentuk penelitian terpadu tahun 2017 dengan Surat Keputusan Walikota No 40 Tahun 2017 tentang Pembentukan Tim Terpadu Penelitian Lokasi Pembangunan Instalasi Pengolahan Air Limbah Milik Pemerintah Kota Banda Aceh di Gampong Pande dan Gampong Jawa, Kecamatan Kutaraja, Kota Banda Aceh

Tim Peneliti Komprehensif IPAL bertugas melaksanakan penelitian ilmiah berdasarkan kaidah dan metode yang sistematis untuk memperoleh data dan informasi berkenaan dugaan lokasi dimaksud merupakan situs arkeologi. Tujuan pembentukan tim terpadu adalah penyiapan hasil laporan bagi Walikota Banda Aceh dan pemangku kepentingan lainnya sebagai bahan pertimbangan dan saran bagi penentuan kebijakan terhadap pembangunan IPAL itu. Tim pelaksana kajian meliputi beberapa unsur yakni pihak Pemkot Banda Aceh, Dinas Diknas Banda Aceh, 
BPCB Banda Aceh, akademisi Universitas Syah Kuala, Ikatan Ahli Arkeologi Indonesia, dan pemerhati sejarah Aceh (Laporan Tim IPAL Kota Banda Aceh, 2017: 1).

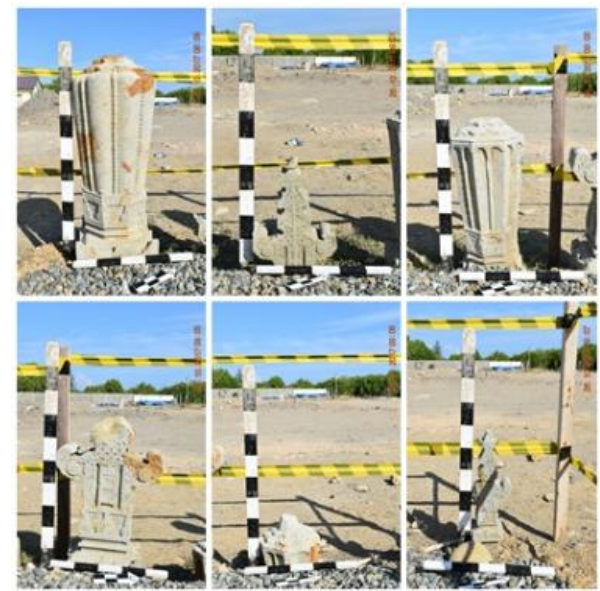

Gambar 1. Tipe nisan kuno yang ditemukan di lokasi IPAL (Sumber: Laporan Tim IPAL Kota Banda Aceh, 2017: 44) Tipe nisan Peta sebaran objek diduga cagar budaya di dekat lokasi IPAL

Bulan November tahun 2017 hasil penelitian Tim IPAL melakukan ekspos dihadapan Walikota Banda Aceh, disimpulkan bahwa lokasi IPAL di Gampong Panda dan Gampong Jawa Kota Banda Aceh merupakan areal situs dengan karakter temuan Situs Kompleks Makam Kuno peninggalan era Kerajaan Aceh Darussalam dengan kerangka waktu relatif antara abad ke17 sampai dengan akhir abad ke-18 Masehi berdasarkan tipologi tinggalan nisan kunonya. Artinya, temuan material nisan di lokasi IPAL adalah benda budaya yang khas tinggalan kerajaan Aceh Darussalam.

Tim IPAL juga menyebutkan bahwa selain nisan-nisan kuno, ditemukan juga berbagai jenis keramik, stoneware dan tembikar dari berbagai era.

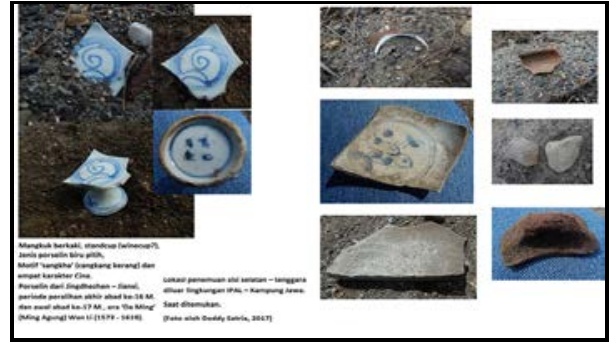

Gambar 2. Temuan keramik, stoneware dan tembikar di lokasi IPAL (Sumber:

Laporan Tim IPAL Kota Banda Aceh, 2017: 63-73)

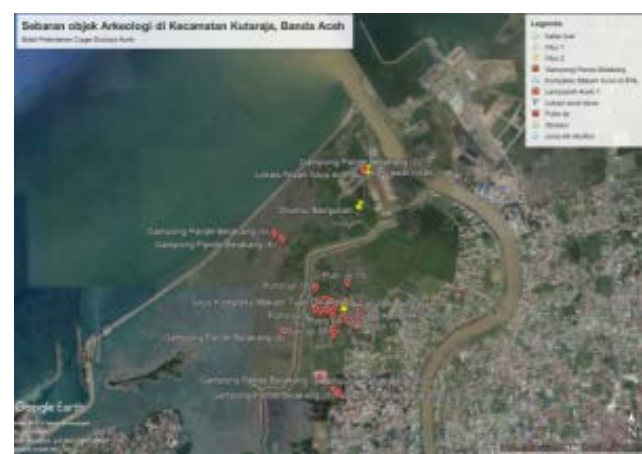

Gambar 3. Peta sebaran objek diduga cagar budaya di dekat lokasi IPAL

(Sumber:

https://kebudayaan.kemdikbud.go.id/bpcb aceh).

Secara material temuan objek tersebut memenuhi unsur formil sebagai objek yang diduga cagar budaya sebagaimana yang dituangkan dalam Undang-Undang No. 11 Tahun 2010 tentang Cagar Budaya pasal 5 bahwa benda, bangunan, atau struktur dapat diusulkan sebagai benda cagar budaya, bangunan cagar budaya, atau struktur cagar budaya apabila memenuhi kriteria yakni memiliki usia di atas 50 tahun, mewakili masa gayapaling disingkat 50 tahun, memiliki arti khusus bagi sejarah, ilmu pengetahuan, pendidikan, agama, dan/atau kebudayaan serta memiliki nilai budaya bagi penguatan kepribadian bangsa (Undang-Undang No.11 Tahun 2010 Tentang Cagar Budaya: 12). 
Tidak hanya di lokasi IPAL saja ditemukan tinggalan artefak arkeologis peninggalan Kerajaan Aceh Darussalam, ternyata areal sebarannya lebih luas lagi di Kecamatan Kutaraja sebagaimana hasil kegiatan pendataan Balai Pelestarian Cagar Budaya Aceh dan Balai Arkeologis Sumatera Utara tahun 2017.

Hasil kajian pustaka Tim IPAL menemukan bahwa berdasarkan hasil kajian riwayat peletakan lokasi IPAL, diketahui ternyata areal ini masuk dalam areal Kawasan Cagar Budaya Gampong Pande sebagaimana yang dimaksud dalam dokumen Rancangan Tata Ruang Wilayah (RTRW) Provinsi Aceh Tahun 2013-2033.

Demikian juga kegiatan Lembaga Swadaya Masyarakat bernama Masyarakat Pemerhati Sejarah Aceh (MAPESA) juga melaporkan banyak temuan situs di Kecamatan Kutaraja yang selama ini belum terdata telah dipublikasi dalam website https://www.mapesaaceh.com.

Kegiatan penelitian yang dilakukan Dinas Pariwisata dan Kebudayaan Kota Banda Aceh (Sekarang Dinas Pendidikan dan Kebudayaan) bekerjasama dengan Balai Arkeologi Medan (sekarang Balai Arkeologi Sumatera Utara) tahun 2003 lalu telah menjelaskan banyaknya tinggalan arkeologi di Gampong Pande dan Gampong Jawa yang perlu diselamatkan (Dipenbud Banda Aceh, 2017).

Kegiatan terbaru inventarisasi atau pendataan potensi cagar budaya di Kota Banda Aceh yang dilakukan Balai Pelestarian Cagar Budaya Aceh tahun 2017 menghasilkan dokumen potensi cagar budaya yang tersebar di
Kecamatan Kutaraja meliputi Gampong Pande dan Gampong Jawa (BPCB Aceh, 2017).

Selain itu, banyak laporan lisan dari masyarakat ke Dinas Pendidikan dan Kebudayaan Kota Banda Aceh memperlihatkan besarnya potensi objek di duga cagar budaya yang masih ada dan perlu di eksplorasi lagi di Gampong Peulanggahan, Gampong Merduati, Gampong Lampaseh, Gampong Keudah, Gampong Jawa dan Gampong Pande di kecamatan Kutaraja, Kota Banda Aceh.

\section{Permasalahan}

Konflik kepentingan atas penggunaan lahan di bekas ruang inti Kerajaan Aceh Darussalam semakin mengkhawatirkan karena menyebabkan kerusakan langsung pada tinggalan budaya yang ada di tempat tersebut. Apabila kondisi ini tidak mendapatkan perhatian serius dari berbagai stakeholder maka kehancuran tinggalan warisan budaya akan berlangsung terus menerus dan tidak terhindarkan.

Sumber konflik saat ini, utamanya terkait kebutuhan lokasi pembangunan proyek-proyek pemerintah di Kota Banda Aceh dan kebutuhan lahan (khususnya perumahan) bagi warga. Jika tidak ditangani secara cepat, dikhawatirkan berbagai tinggalannya akan musnah tidak tersisakan. Ini berarti bangsa Indonesia akan kehilangan satu warisan budayanya yang sangat bernilai penting bagi sejarah, ilmu pengetahuan, pendidikan, agama dan kebudayaan. 


\section{METODE}

Melahirkan kebijakan menjaga warisan Bandar Aceh Darussalam di Kota Banda Aceh dapat dilakukan dengan pendekatan Cultural Resource Management (CRM) atau Manajemen Sumberdaya Budaya. CRM merupakan sebuah kajian yang berkaitan dengan pengelolaan objek-objek (Pearson dan Sullivan, 1995: 7-11). Dengan CRM kita dapat melihat sumberdaya budaya dari perspektif nilai penting, hambatan dan peluang pengelolaanya. Dari bahan ini kita dapat menentukan rancangan kebijakan hingga melahirkan strategi pelaksanaan dan pengelolaan serta monitoring yang berkelanjutan. Adapun metode penulisan karya ini, menggunakan pendekatan induktif, dimana datadata yang sangat beragam berupa hasil studi lapangan dan kepustakaan disusun untuk menarik kesimpulan. Teknik analisis datanya bersifat deskriptif-kualitatif.

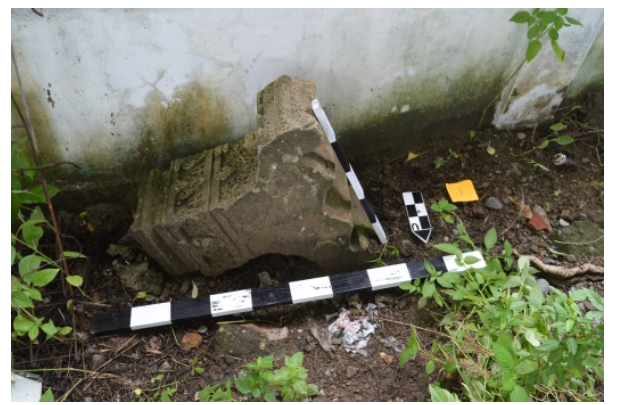

Gambar 4. Kondisi nisan di Alue Deah Tengoh di Kecamatan Meuraksa, Kota

Banda Aceh (Sumber: BPCB Aceh, 2018)

\section{HASIL PENELITIAN}

Hilangnya bukti sejarah bangsa adalah hilangnya satu jati diri yang tidak akan pernah tergantikan. Jika hal ini terjadi maka kehilangan besar tersebut adalah bencana kebudayaan yang selalu diratapi

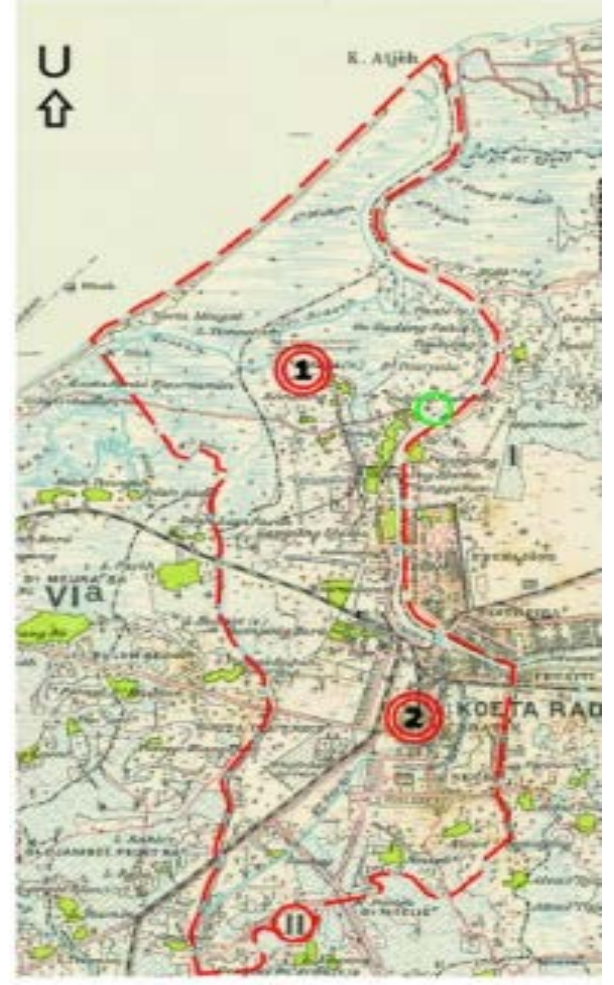

Gambar 11. Peta Kolonial Belanda terkait kondisi Kutara Raja pada Tahun 1898 (Sumber: Laporan Tim IPAL Kota Banda Aceh, 2017)

seluruh anak bangsa dimanapun ia berada. Perumpamaan ini, menjelaskan kondisi keterancaman yang sedang dialami sebaran potensi cagar budaya yang ada di Kecamatan Kutaraja, Banda Aceh.

Semua ahli tentang Aceh menyepakati hakekat wilayah ini, merupakan bekas Bandar Aceh Darussalam dari Kerajaan Aceh yang sangat mashyur. Sebelum menjadi ibukota Kerajaan Aceh, fakta arkeologis menunjukan bahwa awal mula lokasi ini dari kota kecil tempat pedagang beraktivitas, kemudian berkembang menjadi kota kerajaan yang ramai.

Sebuah peta kuno tahun 1898 Masehi dibuat kolonial Belanda (setelah menduduki Bandar Aceh Darussalam Tahun $1874 \quad$ M) 


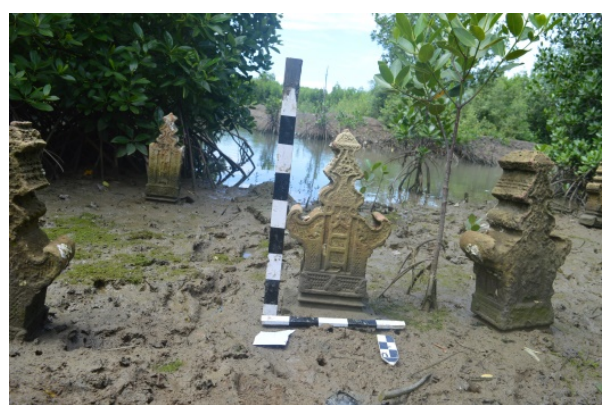

Gambar 5. Kondisi nisan kuno yang berada di areal tambak di Kompleks Makam Putroe Ijo 4 di Kecamatan Kutaraja, Kota Banda Aceh (Sumber: BPCB Aceh, 2018)

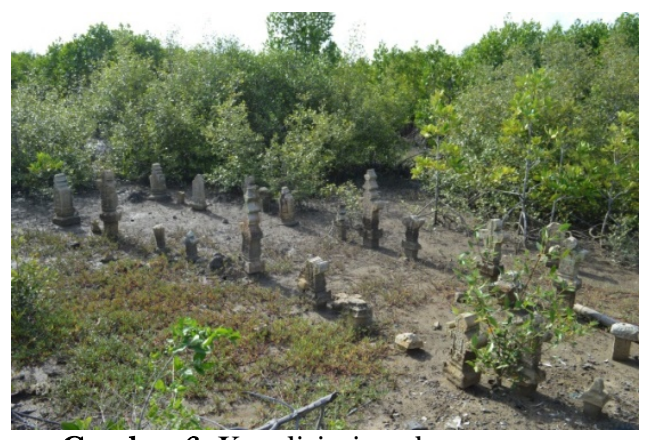

Gambar 6. Kondisi nisan kuno yang berada di areal tambak di Kompleks Makam Putroe Ijo 12 di Kecamatan Kutaraja, Kota Banda Aceh (Sumber: BPCB Aceh, 2018)

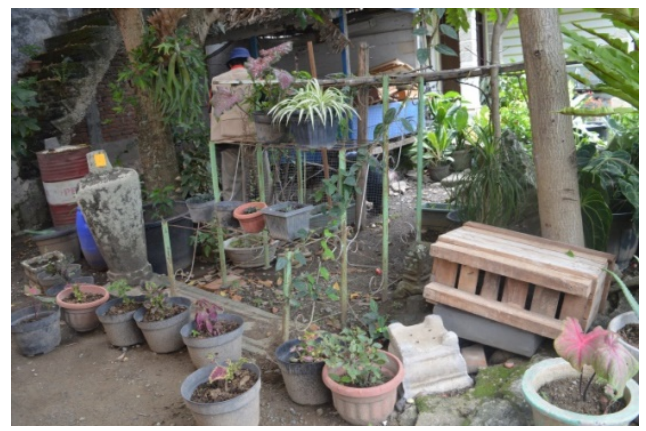

Gambar 7. Kondisi nisan kuno yang berada di halam rumah warga di Gampong Lamseupeng, Kecamatan Lueng Bata, Kota Banda Aceh (Sumber: BPCB Aceh, 2018)

menjelaskan adanya jejak permukiman kuno yang lebih dekat dengan garis pantai dan muara sungai (krueng) Aceh (Gambar 11, lingkaran 1). Permukiman kuno (bagian dari kerajaan Lamuri) ini merupakan

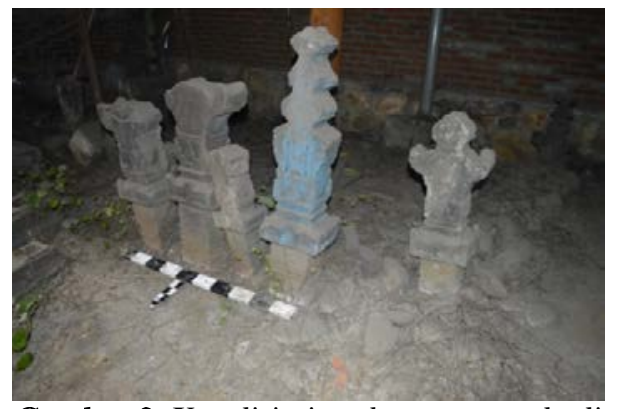

Gambar 8. Kondisi nisan kuno yang ada di dalam rumah toko (ruko) warga di Simpang Surabaya, Kecamatan Lueng Bata, Kota Banda Aceh (Sumber: BPCB Aceh, 2018)

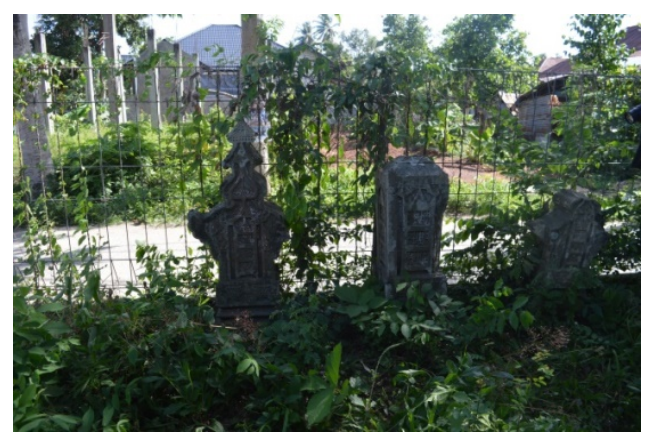

Gambar 9. Kondisi nisan kuno yang ada di areal bengkel di Gampong Suka Damai, Kecamatan Lueng Bata, Kota Banda Aceh (Sumber: BPCB Aceh, 2018).

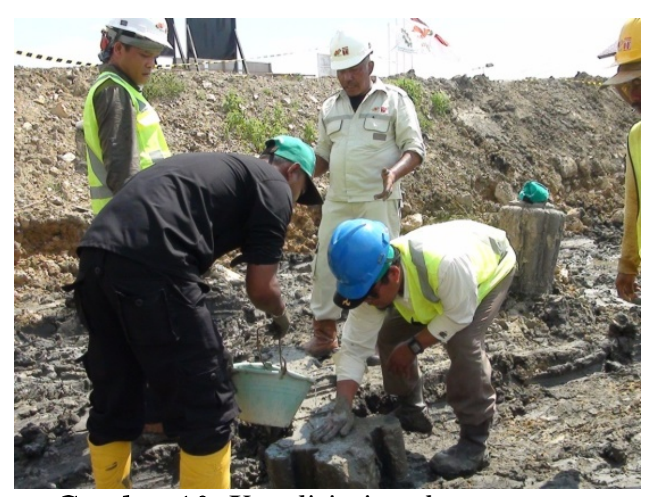

Gambar 10. Kondisi nisan kuno yang ditemukan di lokasi proyek IPAL di Gampong Pande, Kecamatan Kutaraja, Kota Banda Aceh (Sumber: Laporan Tim IPAL Kota Banda Aceh, 2017).

pusat kegiatan perdagangan sebelum berdirinya Kerajaan Aceh Darussalam dengan sultan pertamanya bernama Sultan Ali Mughayat Syah (1507-1523 M). 


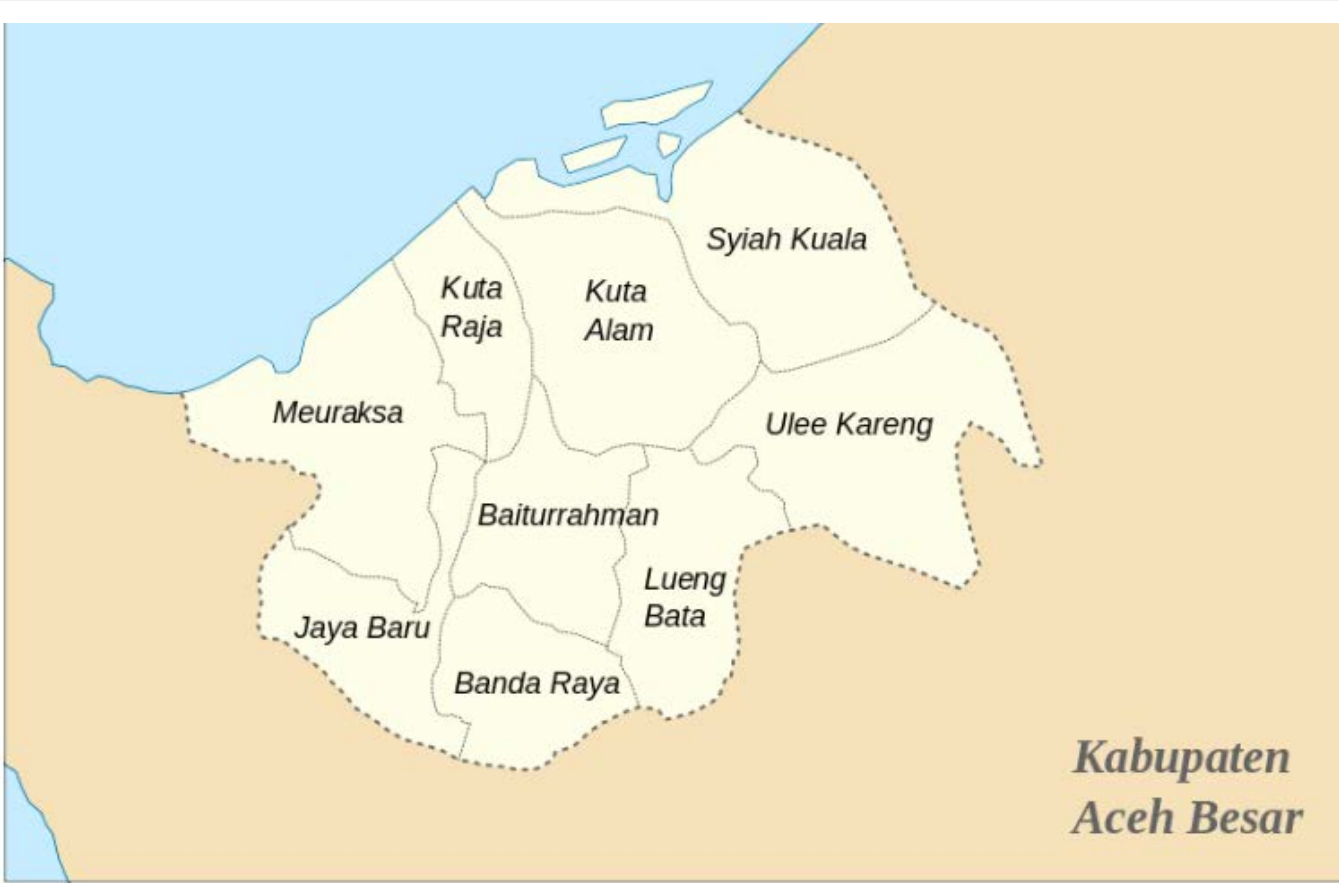

Gambar 12. Peta Pembagian ruang kecamatan di Kota banda Aceh (Sumber: Googgle Maps; dimodifikasi Ambo Asse Ajis)

Kehidupan pemerintahan kerajaan terus berlanjut hingga sultan Aceh kedua yang bernama Sultan Salahuddin (1523-1537 M).

Setelah pemerintahan Sultan Salahuddin, ia digantikan Sultan Ala'uddin Ri'ayat Syah (1537-1571 M). Pada masa pemerintahan sultan ini, tercatat pemerintahan telah berpusat di Bandar Aceh Darussalam sebagaimana yang dituliskan oleh Muhammad Said (1981: 174). disebutkan pada masa beliau pemerintahan sudah sangat luas hingga ke Pariaman, Sumatera Barat. Di tempat ini ada Wakil Sultan Aceh yang menjabat sebagai Raja Pariaman bergelar Sultan Moghul.

Istana kerajaan dibangun lebih luas dengan kota yang dilengkapi tembok keliling (benteng) berikut didalamnya tempat balairung untuk musyawarah, pertemuan, penerimaan tamu-tamu. Selain itu juga terdapat kediaman para keluarga Raja, para Bangsawan dan sebagainya.
Istana sendiri dikenal dengan nama Dalam, lebih kurang seperti makna Kraton di Jawa. Istana Kerajaan akhirnya dipindahkan Sultan dari pusat pemerintahan lama Kerajaan Aceh ke lokasi pemerintahan baru (Gambar 11, lingkaran 2) dan membentuk kota baru yang melahirkan kawasan istana Daruddonya.

Disebutkan dalam riwayat sebelum deklarasi pendirian Kerajaan Aceh, tempat ini menjadi saksi heroisme para Sultan Aceh bersama prajurit kerajaan melawan penjajahan kolonial Portugis dan Belanda. Dari lokasi ini pun kegiatan diplomasi, kegiatan perdagangan dikembangkan, penyebaran Islam aktif dilakukan di nusantara dan banyak lagi lainnya.

Di areal Bandar Aceh Darussalam, aktivitas penduduk dari kegiatan militer, perdagangan, pemerintahan terus tumbuh dan berkembang sesuai keadaan. Secara keruangan, kita melihat kekayaan 
aktivitas budaya di masa lalu Bandar Aceh Darussalam dapat di bagi atas tiga ruang, yakni, kawasan istana Daruddonya, kawasan bandar dan kawasan permukiman penduduk.

Pertama, kawasan istana Daruddonya atau yang dalam naskah disebut dalam merupakan areal paling rahasia kerajaan yang menjadi pusat aktivitas keistanaan Kerajaan Aceh. Di tempat ini, Sultan (Raja), permaisuri dan keturunan serta pengawalnya tinggal, mengatur segala kepentingan kerajaan baik internal maupun eksternal. Ditempat ini juga para tamu kerajaan di jamu dan diperlakukan istimewa. Pada masa sekarang, areal istana Daruddonya melingkupi Kecamatan Baiturrahman.

Kedua, kawasan bandar yakni areal perdagangan kerajaan yang dijalankan langsung oleh Sultan. Menurut data tertulis, lokasi bandar yang dikelola langsung oleh Sultan Aceh ada tiga tempat, yaitu, bandar Aceh (Banda Aceh), bandar Pedir (Pidie) dan bandar Pasai (Aceh UtaraLhokseumawe). Adapun bandar lain yang sangat banyak jumlahnya, dikelola oleh wakil Sultan Aceh, yakni seorang pemimpin yang bergelar Uleebalang, bertugas sebagai perpanjangan tangan Sultan Aceh, seperti, Bandar Daya, Bandar Tumihang, Bandar Meulaboh, Bandar Tiku, Bandar Pariaman dan sebagainya. Ketiga, kawasan permukiman merupakan areal perkampungan penduduk yang berada di sekitar bandar yang dikelola langsung oleh Sultan Aceh.

\section{Potensi Sebaran Tinggalan Arkeologi di Kota Banda Aceh}

Salah satu tinggalan arkeologi yang masih ada saat ini adalah bekas- bekas permukiman kuno yang bisa ditinjau dari tofonomi nama gampong-gampongnya. Pada masa lalu, ada tradisi yang berkembang dalam penamaan sebuah gampong baru di Aceh, di mana seringkali penamaan tersebut dikaitkan dengan situasi asal mula pelaku pendirian gampong, misalnya berdasarkan asal usul yang membuka gampong, atau berdasarkan keberadaan bendabenda alam di awal gampong tersebut dihuni.

Tradisi diatas juga berlaku di berbagai belahan negeri di Indonesia, termasuk wilayah Asia Tenggara. Di Jakarta ada nama Kampung Makassar terkait dengan sejarah orang Makassar yang bermukim di tempat tersebut. Di Malaysia ada Kampung Acheh, tepatnya di Yan Kedah, Malaysia; di Thailand ada nama Kampung Jawa yang berada di daerah Sathorn, Bangkok, Thailand; dan banyak lagi lainnya.

Di Kota Banda Aceh secara umum, tradisi penamaan gampong (desa) juga ada yang mengikuti penamaan asal usul penduduknya. Sebagai contoh, di Kecamatan Kutaraja, beberapa penamaan gampong dikaitkan asal usul kebangsaan penduduknya, seperti 1) Gampong Keudah yang diasosiasikan sebagai bekas perkampungan orang Keudah (Malaysia) atau penduduk Keudah dari Kerajaan Samudera Pasai, 2) bekas perkampungan orang Jawa berada di Gampong Jawa, bekas tinggal penduduk Jawa era kerajaan Aceh, 3) bekas tempat tinggal orang Pahang di Jurong Pahang, di Gampong Jawa yang sangat ramai pada era Sultan Iskandar Tsani Alauiddin Mughayatsyah (1636-1641 Masehi). 
Begitu juga di Kecamatan Kuta Alam, bekas tepat tinggal orang Melayu ada di Jurong (lorong; dusun) Melayu, Kecamatan Kuta Alam. Hal yang sama pada bekas tempat tinggal penduduk klieng (India) yang dinamakan Jurong klieng yang saat ini berada di Gampong Lamdingin, Kecamatan Kuta Alam. Di kecamatan ini juga banyak sekali ditemukan kelompok-kelompok makam dengan tipe nisan plak plin khas Lamuri, tipe Pasai dan tipe Aceh Darussalam.

Sementara itu, bekas tempat tinggal orang Turki (Othman) di kenal dengan nama Gampong Bitay (bait al maqdis) dan Gampong Empeerum (Rum) berada di Kecamatan Jaya Baru.

Di kecamatan Meuraksa ada nama Gampong Surien (Syria; Suriah) di Kecamatan Jaya baru. Gampong ini dikaitkan dengan keberadaan masyarakat Syiria yang pernah menghuni gampong ini. Di kecamatan ini juga ditemukan kelompok-kelompok makam tipe Aceh Darussalam.

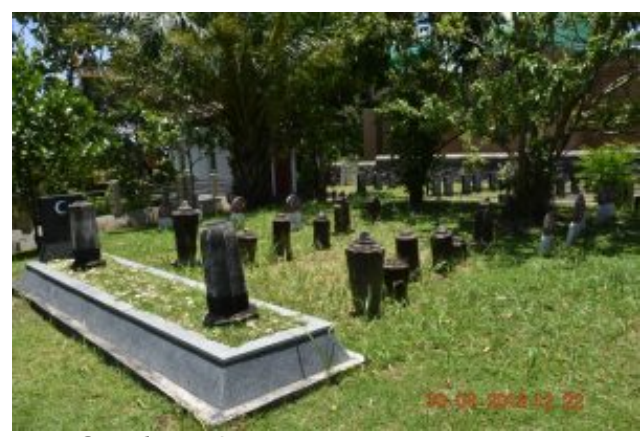

Gambar 13. Situs Kompleks Makam Teungku Chik Dibitay, di Gampong Bitay, Kecamatan Jaya Baru, Banda Aceh

Keberadaan kampungkampung tua di atas, juga dibuktikan dengan berbagai peninggalan akeologis yang tersebar seperti: Gampong Pande, Gampong Jawa,
Gampong Peulanggahan, Gampong Keudah, Gampong Merduati dan Gampong Lampaseh, terdapat kompleks makam kuno dengan kandungan arkeologis berupa nisan tipe Plak Plin (khas Kerajaan Lamuri), tipe Pasai (khas Kerajaan Samuder Pasai) dan Tipe Aceh yang khas berkembang di era Kerajaan Aceh Darussalan.

Kondisi objek ini ada yang dalam kondisi baik dan ada yang memprihatinkan. Ada yang terawat oleh pemerintah dan banyak yang terbengkalai. Selain berbagai tipe nisan, juga jirat, tempat makam berupan dinding tembok atau pondasi juga ada serta sebaran keramik dan tembikar serta bekas bangunan yang terlantar.

Di Kecamatan Baiturrahman, sebaran tinggalan arkeologis sangat melimpah, seperti Mesjid Baiturrahman, makam Kandang XII, Makam Kandang dan Gunongan di Kompleks Tamansari Gunongan, Pintu Khop, bekas istana Kerajaan Aceh, keberadaan dinding istana dan juga keberadaan saluran air (kanal) yang disebut dengan nama Krueng Daroy.

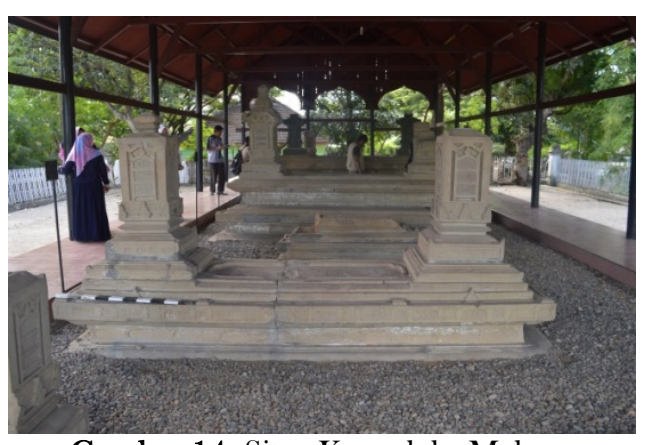

Gambar 14. Situs Kompleks Makam

Kandang XII di Gampong Baru, Kecamatan Jaya Baru, Banda Aceh

Demikian juga di kecamatan Lueng Bata, sebaran makam-makam 
kuno juga ditemukan tepat berada di tepi sungai Aceh (Krueng Aceh), seperti, Kompleks Makam Lamseupeng 1 dan 2, Kompleks Makam tengku Chik Panteriek dan banyak lagi lainnya.

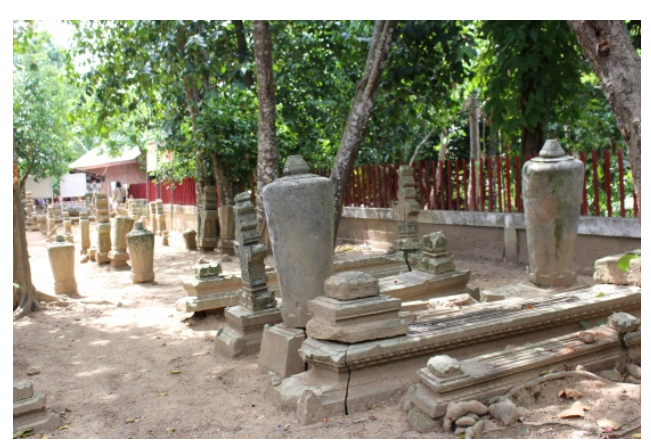

Gambar 15. Situs Kompleks Makam

Teungku Chik Panteriek di Gampong

Panterik, Kecamatan Lueng Bata, Banda Aceh

Di Kecamatan Syiah Kuala juga ditemukan kompleks makam kuno seperti, Kompleks Makam Syiah Kuala, Situs Kompleks Makam Tunggal I dan II dan sebagainya.

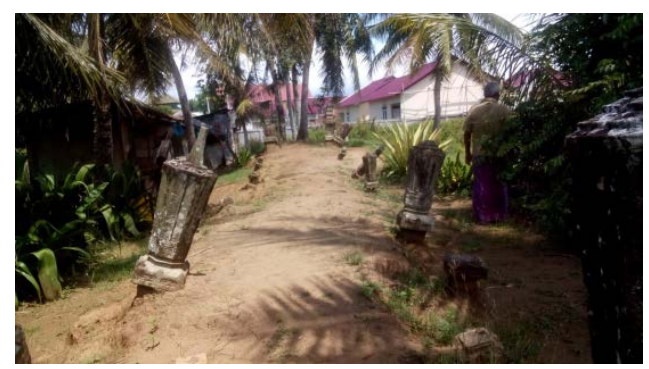

Gambar 16. Situs Kompleks Makam Tunggal I dan II di Gampong Lamgugop, Kecamatan Syiah Kuala, Banda Aceh

Berdasarkan

hasil pengamatan atas makam-makam kuno ternyata menunjukan beberapa hal, yaitu: pertama, keletakan pemukiman-pemukiman kuno di Bandar Aceh Darussalam, ternyata terhubung satu sama lain dengan koneksitas jalur transportasi air. Ada rute yang menghubungkan pesisir pemukiman di pesisir pantai dengan pemukiman yang berada di jalur sungai yang saat itu adalah pusat perkampungan sekaligus kehidupan ekonomi penduduk di era kerajaan Aceh. Dengan kata lain, keletakan perkampungan kuno ini sekaligus adalah bagian integral dari aktivitas Bandar Aceh Darussalam di Kerajaan Aceh itu sendiri.

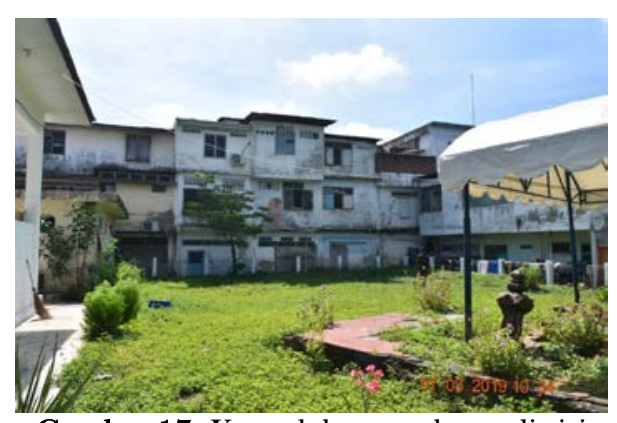

Gambar 17. Kompleks pertokoan di sisi timur pagar dahulunya ada makam kuno yang menjadi bagian dari situs Kompleks Makam Saidil Mukammal di Gampong Merduati, Kecamatan Kutaraja
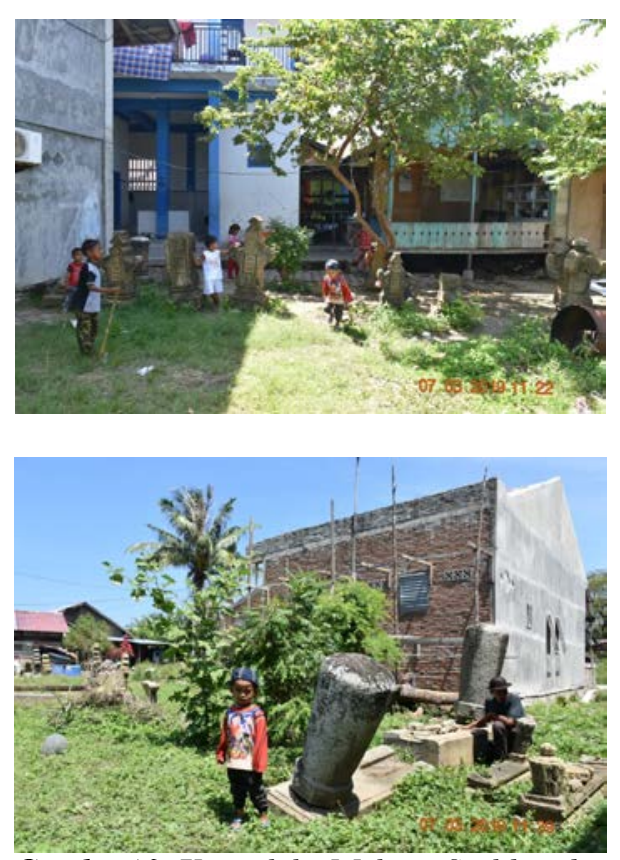

Gambar18. Kompleks Makam Syahbandar Mukhtabar Khan di Gampong Jawa,

Kecamatan Kutaraja, Banda Aceh yang lokasinya berhimpitan dengan pembangunan rumah warga. 
Kedua, kesamaan prilaku sistem penguburannya, dimana tinggalan makam-makam kuno berada di areal perkampungan yang disebut kompleks pemakaman keluarga. Kompleks pemakaman keluarga adalah kompleks pemakaman yang dibuat tidak jauh dari rumah tempat keluarga yang masih hidup. Artinya, rumah hunian keluarga berada satu areal tanah dengan kompleks makam kelurga itu sendiri. Demikian juga atribut-atribut yang digunakan dalam kompleks makam tersebut sangat berbeda dengan makam dari orang-orang biasa, seperti tipologi nisan yang dipilih, ornamen ukiran pada nisan dan jirat, ukuran nisan dan jirat, penggunaan diway (dinding pembatas komples makam keluarga) serta ada perlakuan meninggikan lahan pekuburan sebagai bentuk penghargaan. Perlakuan kompleks makam yang demikian, menandakan ada keistimewaan yang dimiliki keluarga tersebut di masyarakatnya. Apakah ia seorang pejabat di kesultanan Aceh, seorang kaya raya, seorang terpelajar, seorang ulama dan kategori sosiologis lainnya.

Ketiga, banyak temuan arkeologi yang sangat penting di bekas perkampungan-perkampungan kuno Bandar Aceh Darussalam, seperti tembikar, porselin, wadah pelebur logam, manik-manik, kaca, koin dan sebagainya yang tersebar dan belum mendapatkan penangan yang baik.

\section{Keterancaman Potensi Cagar Budaya di Banda Aceh}

Tinggalan arkeologi di atas telah banyak diungkap para pihak, baik itu peneliti asing, peneliti nasional maupun peneliti lokal; dilakukan sendiri-sendiri ataupun bersama-sama oleh kelompok masyarakat, lembaga universitas ataupun lembaga resmi negara. Artinya, kekayaan data arkeologis di bekas Bandar Aceh ini, telah lama dikenal dan mendapatkan perhatian serta pengakuan yang tinggi.

Meskipun Kota Banda Aceh sangat kaya dengan tinggalan arkeologis dan historis, persoalan pelestarian cagar budaya ini ternyata memiliki banyak sekali permasalahan. Ada beberapa persoalan kinerja yang sangat substantif, yakni: pertama, belum adanya database yang menegaskan secara kuantitatif besaran tinggalan cagar budaya di Banda Aceh; kedua, belum sinerginya para stakeholder bidang cagar budaya terkait visi misi pelestarian; ketiga, belum ada visi misi Pemerintah Kota Banda Aceh dan Provinsi Aceh yang mendasari kerja-kerja pelestarian cagar budaya

Di lain sisi, desakan pertumbuhan populasi penduduk dan kebutuhan akan perumahan serta kebutuhan lokasi pembangunan proyek pemerintah juga persoalan nyata yang justru lebih mengemuka dan sangat rawan koflik.

Kasus konflik lahan terus mengancam dan akan semakin meningkat berhimpitan satu sama lainnya. Kondisi seperti ini juga pernah terjadi ketika pada saat kejadian Tsunami tahun 2004 lalu dimana banyak tinggalan arkeologis yang terkena dampak dan sebagian besar terbawa arus gelombang. Akibatnya situs tersebut hancur dan ada yang tertimbun.

Pasca tsunami, pembangunan fisik berupa rumah-rumah bantuan juga terus digalakkan. Sayangnya, kebijakan pembangunan tersebut 
cenderung mengabaikan keberadaan cagar budaya yang mereka temukan saat menggali. Tidak sedikit kasus yang dilaporkan pegiat cagar budaya bahwa pembangunan proyek rumah, perluasan saluran air maupun pembangunan jalan dilakukan dengan cara menggusur bekas kompleks makam kuno.

\section{CRM sebagai Strategi Pelindungan,} Pengembangan dan Pemanfaatan Potensi Cagar Budaya di Banda Aceh Kota Banda Aceh sedang memperbaiki citranya sebagai salah satu kota pusaka di Indonesia. Kesadaran ini lahir atas pemahaman keberadaan objek cagar budaya di Banda Aceh yang dapat dimanfaatkan untuk meningkatkan pertumbuhan ekonomi dari sektor pariwisata. Nilai ekonomi inilah yang didorong dan didukung dalam bentuk program seperti membentuk Tim Registrasi Cagar Budaya Kota Banda Aceh dan Tim Ahli Cagar Budaya Kota Banda Aceh.

Sumberdaya arkeologi adalah bahan penting kota pusaka yang menjadi bukti prilaku manusia masa lampau di Kota Banda Aceh. Tinggalan arkeologi mempunyai nilai dan makna informatif, simbolik, estetik, dan ekonomi (Lipe, 1984). Dalam bidang ekonomi, benda budaya tinggalan masa lampau dapat menjadi asset wisata ekonomi yang menjadi daya tarik karena mempunyai karakter dan keunikannya sendiri. Kekuatan yang dimilikinya ini menjadi sumber daya tarik wisata global yang terdiri atas tiga komponen yaitu wisatawan, geografi, dan industri pariwisata (Cooper et al. 1995: 3).

Sumber daya arkeologi yang ada di Banda Aceh merupakan bagian suatu kawasan yang besar melingkupi era dari masa pra kerajaan hingga modern. Panjang kehidupan masa lalu tersebut membutuhkan pemahaman kotekstual keruangan yang nantinya bisa dibuatkan kebijakan pembagian ruang (zonasi) dari masing-masing komponen (situs) yang ada di Kota Banda Aceh. Dalam hal ini, konsep keruangan bisa mengacu bentuk bentuk kemukiman, kecamatan ataupun kedekatan tinggalan arkeologis satu sama lain. Misalnya, Zona Masjid Raya yang meliputi: Masjid Raya Baiturrahman, Kompleks Makam Sultan Badrul Munir, Situs Kompleks Makam Saidil Mukammal dan situs lain sekitarnya; Zona Gampong Pande, meliputi seluruh objek yang ada di Kecamatan Kutarajaja; Zona Istana dan Taman Bustanussalatin, meliputi: bekas istana, taman ghairah, Kompleks Makam Kandang XII, Kompleks Makam Raja-Raja Keturunan Bugis, Kompleks Makam Kandang Meuh I dan II, dan objek yang berdekatan lainnya.

Berbagai zona tinggalan arkeologis di atas adalah sumber daya budaya (cultural resource) Bandar Aceh Darussalam yang memiliki nilai penting tinggi. Karenanya jika dikelola dengan baik maka dapat mendatangkan banyak keuntungan termasuk keuntungan ekonomi.

Dalam banyak kasus pengelolaan sumberdaya budaya yang baik, objek-objek tersebut berhasil menarik minta kunjungan masyarakat (wisatawan) ke situs-situs arkeologi. mereka mengikuti tur sejarah dan peradaban dalam paket wisata yang telah disiapkan sebelumnya oleh penyelenggara (travel). Dalam hal yang sama, para pengunjung yang 
datang sendiri juga dapat melakukan tournya sendiri sesuai keinginan pengunjung yang tentu memberikan cita rasa pengalaman berarti bagi wisatawan. Pada saat mereka berziarah ke kompleks makammakam kuno baik itu kompleks makam raja, ulama, atau pahlawan kerajaan, tentunya masyarakat akan ada sebagian yang merasa masuk atau tenggelam ke dunia masa lalu. Mereka datang ke kompleks makammakam kuno ini sebagian ada yang mempunyai tujuan untuk menghormat atau menghadap kepada raja atau tokoh yang mereka hormati.

Dari sekian banyaknya keuntungan yang diperoleh jika mengelola sumber daya budaya secara tepat maka tentu saja kita tidak ingin kasus IPAL di Gampong Pande-Gampong Jawa, Kota Banda Aceh tahun 2017 lalu terjadi lagi dan merusak harmonisasi di masyarakat dan menghancurkan potensi ekonomi yang dihasilkan objek arkeologi tersebut di masa depan. Kasus IPAL menjadi pelajaran berharga bagi pemerintah Kota Banda Aceh sehingga lebih berhati-hati dalam membangun di tanah perkotaan dan mendorong mereka mempersiapkan langkah-langkah antisipasi terkait konflik serupa di masa depan.

$$
\text { Pada tahun } 2018 \text { lalu, }
$$

Pemerintah Kota Banda Aceh melalui Dinas Pendidikan dan Kebudayaan telah melakukan registrasi potensi cagar budayanya dan membentuk Tim Ahli Cagar Budaya (TACB) Kota Banda Aceh. TACB Kota Banda Aceh telah bekerja, berhasil mengusulkan penetapan 6 (enam) objek Cagar Budaya dan Walikota Banda Aceh telah mengeluarkan keputusan penetapan atas objek tersebut Nomor 616/2018

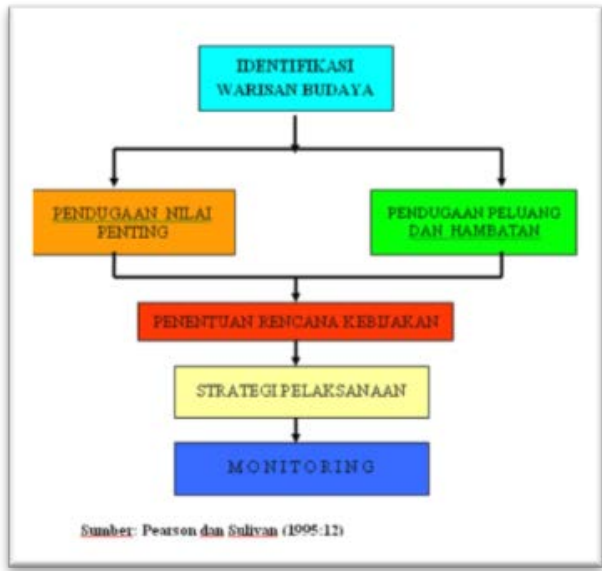

Bagan 1. Kerangka Kerja CRM (Sumber: http://hurahura.wordpress; dimodifikasi Ambo Asse Ajis, 2019)

Penjelasan bagan 1. Langkah pertama, mengidentifikasi yang meliputi pendugaan nilai penting dan pendugaan hambatan dan peluang pengelolaannya. Identifikasi warisan budaya dilakukan baik terhadap masalah bentuk, karakter situs, sebaran, maupun batas wilayah situs sesuai dengan potensi yang dikandung oleh warisan budaya tersebut. Disamping itu, perlu diperhatikan pula, kondisi sosial, budaya, dan ekonomi masyarakat setempat dan interaksi mereka dengan warisan budaya, guna pemahaman terhadap hambatan ataupun peluang dalam pengelolaannya. Langkah kedua, penentuan rancangan kebijakan merupakan langkah penetapan tujuan pelestarian berdasarkan kajian langkah sebelumnya mengenai pendugaan nilai penting dan pendugaan peluang serta hambatannya. Langkah ketiga, pelaksanaan pengelolaan merupakan implementasi dari kebijakan yang sudah dirumuskan sebelumnya. Tahap ini dapat dilakukan misalnya bagaimana menata warisan budaya agar menarik wisatawan tanpa mengurangi nilai penting yang dikandungnya. Langkah keempat, monitoring pelaksanaan merupakan tahap pemantauan sekaligus berfungsi pengevaluasian atas manajemen atau pengelolaan yang telah dilakukan. Oleh karena itu, tahap ini sudah harus ditetapkan sistem, tolok ukur yang dapat dipergunakan sebagai dasar untuk menilai kriteria berhasil tidaknya. (Sulistyanto, 2011). 
tentang Penetapan Situs Makam Teungku Chik Lamjabat, Situs Makam Tunggal I dan II, Situs Makam Saidil Mukammal, Situs Makam Teungku Di Bitay dan Tugu Peringatan Kematian Jenderal Jacobus Hebertus Pel dan Lokasi Bivak Kolonial Belanda sebagai Cagar Budaya.

$$
\text { Pada tahun } 2019 \text { ini, }
$$

Walikota Banda Aceh kembali membentuk TACB Kota Banda Aceh dan telah bekerja menghasilkan 14 naskah yang akan direkomendasi sebagai Cagar Budaya peringkat Kota Banda Aceh.

Apa yang dicapai Pemerintah Kota Banda Aceh tahun 2018 dan 2019 di atas merupakan langkah awal yang sangat bagus dalam mengantisipasi potensi konflik pelestarian. Namun demikin, Pemerintah Kota Banda Aceh harus memiliki rancangan yang lebih komprehensit terkait penanganan cagar budayanya. Salah satu metode penangannya yang seringkali diaplikasikan dalam dunia arkeologi adalah penggunaan pendekatan CRM sebagai solusi manajerial sumber daya arkeologi. Kemampuan CRM sebagai sebuah pendekatan untuk menangani konflik yang terkait dengan sumberdaya arkeologi dijelaskan oleh Fowler (1982: 2) maupun Plog (1978: 422) dimana dikatakan CRM mengutamakan aspek kepentingan pelestarian di satu pihak dan kesejahteraan masyarakat di pihak yang lain. Fowler menjelaskan CRM sebagai suatu upaya penerapan kemampuan pengelolaan (merencanakan, mengatur, mengarahkan, mengendalikan, dan mengevaluasi) guna mencapai tujuan tertentu dalam upaya pelestarian melalui proses politis untuk kepentingan

pencapaian pertumbuhan masyarakat.

Dalam konteks ini, penggunaan CRM di Kota Banda Aceh dapat dilakukan dengan cara sebagai berikut: Pertama, Pemerintah Kota Banda Aceh perlu memiliki acuan kerja dalam bentuk kerangka kerja CRM sistematis. Artinya, stakeholder yang ber-iris-an dengan cagar budaya yang ada di Banda Aceh dilibatkan membicarakan, membahas dan merumuskan konsep acuan kerja CRM. Sebagai contoh, ada kerangka kerja CRM yang bagus dari Pearson and Sullivan yang ditulis oleh Sulistyanto (2011) dalam Majalah Arkeologi.

Kedua, diperlukan tindakantindakan nyata aktivitas pelindungan cagar budaya, antara lain: 1) dibutuhkan keberadaan payung hukum dalam bentuk Qanun (perda) yang menegaskan kegiatan pelindungan cagar budaya pemerintah Kota Banda Aceh dan partisipasi masyarakat didalamnya. 2) dinas yang membidangi kebudayaan, harus memperkuat aparaturnya dalam bekerja meregistrasi objek yang diduga cagar budaya dan mengusulkan kepada Tim Ahli Cagar Budaya Kota Banda Aceh untuk disidang dan diusulkan penetapannya kepada Walikota Banda Aceh. 3) objek yang diduga cagar budaya dan yang telah ditetapkan sebagai cagar budaya peringkat Kota Banda Aceh, dapat diusulkan kenaikan peringkatnya menjadi peringkat Provinsi Aceh maupun peringkat nasional. 4) objek yang diduga cagar budaya dan yang telah ditetapkan sebagai cagar budaya peringkat Kota Banda Aceh dapat difungsikan langsung dalam bentuk kegiatan 
pelindungan, pengembangan dan pemanfaatan setiap tahun anggaran berjalan. Kegiatan pelindungan bisa dilakukan dengan membuat fasilitas pelindungan, melakukan kegiatan konservasi hingga pemugaran. Kegiatan pengembangan bisa dilakukan dengan melakukan aktivitas penelitian untuk kepentingan pengembangan nilai objek, kegiatan revitalisasi dan adaptasi sesuai kondisi zaman sekarang. Kegiatan pemanfaatan dapat dilakukan dengan memanfaatkan objek-objek tersebut untuk berbagai kepentingan, seperti kepentingan ilmu pengetahuan, pendidikan, keagamaan dan kebudayaan.

Ketiga, pelibatan level kepemerintahan di Kota Banda Aceh harus dilakukan sesuai dengan jenjangnya masing-masing, yaitu:

1. Pemerintah Gampong, dapat membuat reusam gampong yang dasar pemikirannya mengikuti pokok pikiran Qanun Cagar Budaya Kota Banda Aceh, memasukkan objek cagar yang diduga cagar budaya maupun cagar budaya sebagai aset gampong yang perlu dilindungi, kembangkan dan dimanfaatkan. Untuk melaksanakannya, bisa menggunakan dana gampong dalam rangka memperbaiki sarana prasarana yang dibutuhkan sesuai penilaian hasil studi teknis.

2. Pemerintah Kecamatan, bisa menjadi inisiator kelembagaan pelindungan dengan cara mengajak stakholder di kecamatan merumusukan strategi pelestarian objek cagar budaya yang ada di gampong-gampong pada kecamatan tersebut.

3. Pemerintah Kota Banda Aceh bersama Dewan Perwakilan Kota
Banda Aceh wajib membuat Qanun Cagar Budaya dan sekaligus mengalokasikan anggaran untuk keperluan pelindungan, pengembangan dan pemanfaatan. Selain itu, juga perlu digiatkan kegiatan pendataan atau inventarisasi potensi cagar budaya dengan melibatkan aparat gampong serta akademisi maupun pemerhati cagar budaya di Kota Banda Aceh.

Keempat, lembaga pemerintah yang bergerak di bidang pelestarian cagar budaya seperti, Balai Pelestarian Cagar Budaya Aceh, Balai Arkeologi Sumatera Utara, UniversitasUniversitas yang ada di Aceh turut bersama pemerintah Kota Banda Aceh merancang model pengelolaan sumberdaya arkeologi yang berkelanjutan. Rancangan ini meliputi cara kerja bersama dalam pembuatan master plan pelestarian yang didalamnya ada desain pelindungan, pengembangan dan pemanfaatan baik itu jangka pendek, menengah maupun jangka panjang.

Keempat hal di atas adalah fondasi menerapkan cultural resources management (CRM) yang menjadi dasar kerja-kerja pelestarian menjaga warisan budaya Bandar Aceh Darusalam. Dengan sinergitas dan fokus pada rencana jangka pendek, menengah dan panjang maka arah dan tujuan pelestarian objek-objek arkeologi dan sumberdaya budaya lainnya yang ada hubungannya dengan Bandar Aceh Darussalam akan terlindungi secara otomatis baik dalam bentuk program maupun aksi sinergitas pelestarian yang terprogram. 


\section{KESIMPULAN}

Penggunaan CRM sebagai strategi menjaga warisan budaya Bandar Aceh Darussalam di Kota Banda Aceh adalah satu dari sekian banyak metode yang bisa dipakai mengelola potensi cagar budaya. Penggunaan metode seperti CRM ini harus dilakukan demi mencegah hilangnya sumberdaya tersebut akibat konflik dan ekses kebijakan yang salah.

Pelindungan, pengembangan dan pemanfaatan bekas Bandar Aceh Darussalam mutlak dilakukan karena ia adalah lokasi sumber ilmu pengetahuan tentang berbagai aktivitas penduduk nusantara jauh sebelum abad ke-15 Masehi dan berlangsung sampai dengan abad ke20 Masehi.

Dari sisi ilmu pengetahuan, tempat ini yang sekarang menjelma menjadi Kota Banda Aceh memiliki potensi kandungan sejarah Pemerintahan Kerajaan Aceh, arkeologi tata kota Kerajaan Aceh, sosiologi masa lampau masyarakat Kerajaan Aceh, kegiatan penyebaran Islam di Kerajaan Aceh, merekam perkembangan berbagai seni yang pada masa Kerajaan Aceh, berbagai keahlian teknis yang berkembang di Kerajaan Aceh sejak abad ke-15 Masehi hingga abad ke-19 Masehi dan tentu masih banyak bidang lainnya yang bisa kita kaji.

Karenanya, kebutuhan mendesak untuk menjaga kekayaan potensi data tersebut perlu dilakukan para stakeholder yang bergerak di bidang pelestarian. Pertama, stakeholder dari pemerintah, meliputi pemerintah Kota Banda Aceh, Provinsi Aceh, Pemerintah Pusat di Jakarta agar segera melahirkan kebijakan pelindungan hukum kawasan ini dengan menerbitkan penetapan lokasi berbagai kawasan cagar budaya, baik itu peringkat Kota Banda Aceh, peringkat Provinsi Aceh maupun peringkat Nasional.

Kedua, pelibatan unsur petugas publik di semua level pemerintahan seperti, aparatur gampong (desa), aparatur kecamatan, lembaga adat, lembaga kepemudaan dan organisisasi yang peduli dengan cagar budaya agar dilakukan secara berkelanjutan baik dalam hal kegiatan pelindungan, pengembangan dan pemanfaatan.

Ketiga, para stakeholder yang ada harus dilibatkan menggagas bersama strategi pelindungan, pengembangan dan pemanfaatan yang dituangkan dalam dokumen rencana kegiatan pelestarian warisan budaya berbagai kawasan cagar budaya di Kota Banda Aceh, baik itu jangka pendek, menengah dan jangka panjang. Terkait dengan pembiayaan kegiatan bisa diadakan pemisahan skala kegiatan: (a) kegiatan gampong (desa) melalui Anggaran Pendapatan dan Belanja Desa (APBDes), (b) kegiatan kecamatan dan program strategis pelestarian objek cagar budaya Kota Banda Aceh melalui Anggaran Pendapatan dan Belanja Kota (APBK) Banda Aceh, (c) kegiatan pelestarian cagar budaya Provinsi Aceh melalui Anggaran Pendapatan dan Belanja Aceh (APBA), dan (d) kegiatan pelestarian cagar budaya nasional melalui Anggaran Pendapatan dan Belanja Negara (APBN).

Keempat, untuk memperkuat kegiatan pelindungan, pengembangan dan pemanfaatan warisan budaya di Banda Aceh bisa dibentuk kelembagaan unit pelaksana teknis (UPT) dan atau membentuk Badan 
Pengelola yang bertanggungjawab melakukan kegiatan pelindungan, pengembangan dan pemanfaatan. Kelembagaan ini bisa dibawah pemerintah Kota Banda Aceh, Pemerintah Provinsi Aceh dan bahkan nasional. Dalam implementasinya, kelembagaan ini diisi para profesional dan ruang keikutsertaan masyarakat juga disediakan.

Kelima, untuk menjaga kepentingan pelestarian warisan budaya sekaligus mengakomodir kepentingan-kepentingan lainnya di Kota Banda Aceh, sangat diperlukan kepastian hukum tinggalan yang diduga cagar budaya dan penerapan perlindungan regulasi. Kepastian hukum yang dimaksud, seperti adanya dokumen hukum secara yuridis formal menyebutkan kedudukan objek tersebut sebagai cagar budaya sehingga dapat diintegrasikan dengan kepentingankepentingan praktis lainnya (seperti pendidikan, pariwisata, penelitian dan sebagainya) serta memuat jaminan ada keterlibatan publik terkait perlakuan objek baik yang diduga cagar budaya maupun cagar budaya.

Dalam sisi yang sama, Pemerintah Kota Banda Aceh juga secara internal perlu melakukan berbagai kegiatan, antara lain 1) pendataan atau inventarisasi potensi cagar budaya, 2) mendaftarkan temuan hasil pendataan, 3) daftar cagar budaya tersebut diajukan kepada Tim Ahli Cagar Budaya (TACB) Kota Banda Aceh untuk dikaji, 4) TACB Kota Banda Aceh mengusulkan objek-objek yang memenuhi syarat untuk direkomendasikan kepada Walikota Banda Aceh agar ditetapkan sebagai cagar budaya peringkat Kota Banda
Aceh serta jika perlu mengusulkan untuk menaikkan peringkat menjadi peringkat Provinsi Aceh dan nasional bahkan jika memungkinan hingga warisan dunia.

Kebijakan menjaga warisan Bandar Aceh Darussalam yang saat ini menjadi Kota Banda Aceh dengan pendekatan Cultural Resource Management (CRM) atau Manajemen Sumberdaya Budaya di atas akan lebih adaptif dengan perkembangan zaman. Setiap konflik berkaitan dengan objek di duga ataupun yang telah ditetapkan sebagai cagar budaya pada akhirnya bisa diselesaikan dalam forum stakeholder yang dibentuk oleh Pemerintah Kota Banda Aceh. Forun ini menjadi jembatan yang menjaga kepentingan semua pihak dengan penyelesaiannya yang lebih pada win-win solution. 


\section{DAFTAR PUSTAKA}

Abdul Jalil, Tuaku. (1991). Adat Meukuta Alam. Seri Informasi Aceh Tahun XIV No.1. Banda Aceh: Pusat Dokumentasi dan Informasi Aceh.

Ambary, Hasan Muarif. (1988). Persebaran Kebudayaan Aceh di Indonesia melalui Peninggalan Arkeologi Khususnya Batu-batu Nisan. Dalam Majalah INTIM. Edisi Khusus no.4 tahun ke-7, hlm. 9-16. Jakarta. - (1998). Kepurbakalaan Aceh Kajian Makam-makam Islam di Aceh.

Naskah dipresentasikan pada Seminar Budaya Aceh oleh Jabatan Pendidikan dan Kebudayaan Aceh.

Anthony Reid. (1992). Asia Tenggara Dalam Kurun Niaga 1450-1680, Jilid I; Tanah di Bawah Angin. Jakarta: Yayasan Obor Indonesia.

Cloude Guilot dan Ludvik Kalus. (2008). 'Les Monuments Foneraires et l'Histoire du Sultananate de Pase a Sumatera', Archipel 37.

Cooper, Chris. (1991). The Technique of Interpretation. Dalam Medlik (ed), Managing Tourism (h. 224-229). Oxford:Butterworth-Heinemann Ltd.

Drewes, G.W.J. (1979). Hikajat Potjut Muhamat An Achehnese Epic. The Hague: Martinus Nijhoff.

Dupoizat, Marie France. (2015). Keramik Berbahan Batuan dan Porselen dari Situs-Situs di Barus Sesudah Labu Tua. Dalam Daniel Perret dan Heddy Surachman (eds), Barus Negeri Kamper Sejarah Abad ke-12 hingga Pertengahan Abad ke-17. Jakarta: Kepustakaan Populer Gramedia.

Fowler, D. (1982). Cultural Resourcer Management. In Advances in Archaelogical Methods and Theory, Volume 5. New York: Academic Press.

Hasjmy, A. (1983). Kebudayaan Aceh dalam Sejarah, Cet.I. Jakarta: Beuna.

Herwandi. (2003). Bungong Kalimah Kaligrafi Islam Dalam Bulatan Tasawuf Aceh (Abad Ke-16-18 M). Padang: Universitas Andalas.

Hoesein Djajadiningrat, R.A. (1980). Upacara Pula Batee Pada Makam Sultan Iskandar II (1636-1641), alih bahasa Aboe Bakar. Banda Aceh: Pusat Dokumentasi dan Informasi Aceh.

Ibrahim, Husaini. (2016). Awal Masuknya Islam ke Aceh: Analisis Arkeologi dan Sumbangannya pada Nusantara. Banda Aceh: Aceh Multivision.

Iskandar, T. (1978). Hikayat Aceh (Kisah Kepahlawanan Sultan Iskandar Muda), alih bahasa Aboe Bakar. Aceh: Proyek Rehabilitasi dan Perluasan Museum Daerah Istimewa Aceh.

Langen, Karel F.H. van, (1986). Susunan Pemerintahan Aceh Semasa Kesultanan, alih bahasa T. Aboe Bakar, Seri Informasi Th. IX/No. 1. Banda Aceh: Pusat Dokumentasi dan Informasi Aceh.

Loir, Henri Chambert dan Ambary, Hasan Mu'arif (eds). (1999). Panggung Sejarah, EFEO, PUSLIT ARKENAS. Jakarta: Yayasan Obor Indonesia. 
Lombard, Denys. (1991). Kerajaan Aceh, Jaman Sultan Iskandar Muda (16071636). Jakarta, Balai Pustaka

Manguin, Pierre-Yves. (1999). Demografi dan Tata Perkotaan di Aceh pada Abad16. Data Baru Menurut Sebuah Buku Pedoman Portugis Tahun 1584. Dalam Henri Chambert-Loir dan Hasan Mu'arif Ambary (eds), Panggung Sejarah, EFEO, PUSLIT ARKENAS. Jakarta: Yayasan Obor Indonesia.

Mohd, Othman Yatim. (1988). Batu Aceh, Early Islamic Gravestones in Peninsular Malaysia. Kuala Lumpur: Muzium Negara.

Pemkot Banda Aceh. (2017). Laporan Penelitian Komprehensif Instalasi Pengelohan Air Limbah Kota Banda Aceh. Tidak dipublikasikan.

Perret, Daniel dan Surachman, Heddy (eds). (2015). Barus Negeri Kamper Sejarah Abad ke-12 hingga Pertengahan Abad ke-17. Jakarta: Kepustakaan Populer Gramedia

Said, Muhammad (1981). Aceh Sepanjang Abad. Medan: Waspada Press.

Sulistyanto, Bambang (2011). Penerapan “Cultural Resource Management”. Dalam Arkeologi Majalah Arkeologi. http://hura.hurawordpress.com, 22 Maret 2019.

Yati, Othman M. (1988). Batu Aceh: Early Islamic in Paninsular Malaysia. Kuala Lumpur: Dewan Bahasa dan Pustaka.

Yati, Othman M. dan Nasir, Abdul Halim. (1990). Epigrafi Islam Terawal di Nusantara. Kuala Lumpur: Dewan Bahasa dan Pustaka 